\title{
Cytotoxic effect of magnetic iron oxide nanoparticles synthesized via seaweed aqueous extract
}

\author{
Farideh Namvar ${ }^{1,2}$ \\ Heshu Sulaiman Rahman ${ }^{3,4}$ \\ Rosfarizan Mohamad ${ }^{1,5}$ \\ Javad Baharara \\ Mahnaz Mahdavi ${ }^{6}$ \\ Elaheh Amini ${ }^{7}$ \\ Max Stanley Chartrand ${ }^{8}$ \\ Swee Keong Yeap ${ }^{3}$
}

'Institute of Tropical Forestry and Forest Products, Universiti Putra

Malaysia, Selangor, Malaysia; ${ }^{2}$ Research

Center for Animal Development

Applied Biology, Mashhad Branch,

Islamic Azad University, Mashhad, Iran;

${ }^{3}$ Institute of Bioscience, ${ }^{4}$ Department

of Microbiology and Pathology,

Faculty of Veterinary Medicine,

${ }^{5}$ Department of Bioprocess

Technology, Faculty of Biotechnology and Biomolecular Sciences, Universiti Putra Malaysia, Selangor, Malaysia; ${ }^{6}$ Department of Chemistry, Faculty of Science, Islamic Azad University, Shiraz Branch, Shiraz, ${ }^{7}$ Kharazmi University, Tehran, Iran; ${ }^{8}$ DigiCare Behavioral Research, Casa Grande, AZ, USA

Correspondence: Farideh Namvar Institute of Tropical Forestry and Forest Products, Universiti Putra Malaysia, 43400 UPM Serdang, Selangor, Darul

Ehsan, Malaysia

Email farideh.namvar@putra.upm.edu.my

Heshu Sulaiman Rahman

Department of Microbiology and

Pathology, Faculty of Veterinary Medicine,

Universiti Putra Malaysia, 43400 UPM

Serdang, Selangor, Malaysia

$\mathrm{Tel}+60389463455$

Fax +6038946 I07|

Email heshusr77@gmail.com
This article was published in the following Dove Press journal:

International Journal of Nanomedicine

19 May 2014

Number of times this article has been viewed

\begin{abstract}
Magnetic iron oxide nanoparticles $\left(\mathrm{Fe}_{3} \mathrm{O}_{4} \mathrm{MNPs}\right)$ are among the most useful metal nanoparticles for multiple applications across a broad spectrum in the biomedical field, including the diagnosis and treatment of cancer. In previous work, we synthesized and characterized $\mathrm{Fe}_{3} \mathrm{O}_{4}$ MNPs using a simple, rapid, safe, efficient, one-step green method involving reduction of ferric chloride solution using brown seaweed (Sargassum muticum) aqueous extract containing hydroxyl, carboxyl, and amino functional groups mainly relevant to polysaccharides, which acts as a potential stabilizer and metal reductant agent. The aim of this study was to evaluate the in vitro cytotoxic activity and cellular effects of these $\mathrm{Fe}_{3} \mathrm{O}_{4} \mathrm{MNPs}$. Their in vitro anticancer activity was demonstrated in human cell lines for leukemia (Jurkat cells), breast cancer (MCF-7 cells), cervical cancer (HeLa cells), and liver cancer (HepG2 cells). The cancer cells were treated with different concentrations of $\mathrm{Fe}_{3} \mathrm{O}_{4}$ MNPs, and an MTT (3-[4,5-dimethylthiazol-2-yl]-2,5 diphenyl tetrazolium bromide) assay was used to test for cytotoxicity, resulting in an inhibitory concentration $50\left(\mathrm{IC}_{50}\right.$ ) value of $23.83 \pm 1.1 \mu \mathrm{g} / \mathrm{mL}$ (HepG2), 18.75 $\pm 2.1 \mu \mathrm{g} / \mathrm{mL}$ (MCF-7), $12.5 \pm 1.7 \mu \mathrm{g} / \mathrm{mL}$ (HeLa), and $6.4 \pm 2.3 \mu \mathrm{g} / \mathrm{mL}$ (Jurkat) 72 hours after treatment. Therefore, Jurkat cells were selected for further investigation. The representative dot plots from flow cytometric analysis of apoptosis showed that the percentages of cells in early apoptosis and late apoptosis were increased. Cell cycle analysis showed a significant increase in accumulation of $\mathrm{Fe}_{3} \mathrm{O}_{4}$ MNP-treated cells at sub-G1 phase, confirming induction of apoptosis by $\mathrm{Fe}_{3} \mathrm{O}_{4} \mathrm{MNPs}$. The $\mathrm{Fe}_{3} \mathrm{O}_{4} \mathrm{MNPs}$ also activated caspase- 3 and caspase- 9 in a time-response fashion. The nature of the biosynthesis and therapeutic potential of $\mathrm{Fe}_{3} \mathrm{O}_{4}$ MNPs could pave the way for further research on the green synthesis of therapeutic agents, particularly in nanomedicine, to assist in the treatment of cancer.
\end{abstract}

Keywords: green synthesis, seaweed water extract, anticancer effect, apoptosis

\section{Introduction}

Nanoscience and nanotechnology have elegant potential across a broad spectrum of cancer research, including diagnostic, monitoring, and therapeutic strategies, and provide novel approaches in these areas. ${ }^{1}$ Some nanocarriers, like liposomes, dendrimers, micelles, carbon nanotubes, and nanoparticles, have been used to help in the diagnosis and theranostics of certain types of cancers. ${ }^{2,3}$ The green approach to synthesis of nanoparticles using plant materials, such as reducing and capping agents, could be considered attractive in nanobiotechnology. When compared with mechanical strategies, this technology is safe, simple, nontoxic, efficient, and environmentally friendly, and also provides efficacious single-pot reactions without the need for additional surfactants or capping agents. ${ }^{4}$

Due to their superparamagnetic behavior and surface modification properties, iron oxides are considered to be capable candidates in cancer therapy. ${ }^{5}$ A novel 
approach to biosynthesis of iron oxide magnetic nanoparticles $\left(\mathrm{Fe}_{3} \mathrm{O}_{4} \mathrm{MNPs}\right.$ ) is to make nanoparticles using natural products, such as plant extracts, to reduce metal ions, which are readily scalable and nontoxic compared with physical and chemical methods. ${ }^{6}$

Synthesis of iron oxide in the presence of an oxidant creates several forms of iron oxides including magnetite $\left(\mathrm{Fe}_{3} \mathrm{O}_{4}\right)$ and hematite $\left(\mathrm{a}-\mathrm{Fe}_{2} \mathrm{O}_{3}\right)$. Application of magnetite type iron oxide nanoparticles have been studied extensively in recent years for their potential beneficial effects. ${ }^{7}$ The unique magnetic properties of iron oxide nanoparticles mean decreased drug expenditure and drug administration, and improved efficacy of diagnosis, targeting, and treatment of tumors. ${ }^{8}$

The biocompatibility of $\mathrm{Fe}_{3} \mathrm{O}_{4}$ MNPs makes them suitable for biomedical application, such as in cellular therapy, tissue repair, drug delivery, and magnetofection. ${ }^{9}$ Recent investigations have focused on developing methods that synthesize magnetic nanoparticles with vast potential including size, charge, stability, shape, and morphology..$^{10}$ In general, due to aggregation behavior, colloidal stability, and cytotoxicity, surface coatings of the nanoparticles are considered critical in nano research. ${ }^{11}$ The biodistribution of these nanoparticles in vivo is greatly affected by their surface coating properties and the influence of an external magnetic field. In addition, a number of biocompatibility assays have been performed for polysaccharide-coated magnetic nanoparticles, due to concerns regarding the risks and benefits of magnetic nanoparticles and related technologies to human health and the environment.

Using $\mathrm{Fe}_{3} \mathrm{O}_{4}$ MNPs in the treatment of cancer, Ling et al reported on superparamagnetic iron oxide nanocrystals concurrently loaded with docetaxel, a chemotherapeutic anticancer drug, and assessed their efficacy as an anticancer agent. The targeted nanoparticles were seen to have an antiproliferative effect in PC3 prostate cancer cells on cytotoxicity assay. The $\mathrm{IC}_{50}$ value for iron nanoparticles loaded with docetaxel was 1.46 -fold and 1.57-fold lower than that of docetaxel after 48 hours and 72 hours of treatment. Furthermore, the nanoparticles alone did not have any significant cytotoxic effect on PC3 cells, suggesting that a drug encapsulated in nanoparticles develops increased cytotoxicity in a time-dependent and dose-dependent manner. ${ }^{12}$

Khan et al evaluated the cytotoxic effects of $\mathrm{Fe}_{3} \mathrm{O}_{4}$ MNPs in A549 human lung epithelial cancer cells and normal IMR-90 lung fibroblasts. In their study, cancerous and normal cells were exposed to various concentrations of $\mathrm{Fe}_{3} \mathrm{O}_{4} \mathrm{MNPs}(1-100 \mu \mathrm{g} / \mathrm{mL})$ for 24 hours and 48 hours. Their findings showed that $\mathrm{Fe}_{3} \mathrm{O}_{4}$ MNPs had significant cytotoxic effects on A549 human lung cancer cells, but not on normal IMR-90 human lung fibroblasts. ${ }^{13}$ Recent studies have also confirmed the fact that bioactive compounds obtained from macroalgae can increases the chances of discovery of novel and versatile pharmaceutical agents with promise in cancer research, diagnostics, and treatment. ${ }^{14}$

As mentioned in previous reports, ${ }^{15}$ seaweed is a subgroup of macroalgae and an available food source in many countries, traditionally those in south-east Asia. ${ }^{16}$ Seaweed contains a number of potentially biologically active ingredients, including polysaccharides, proteins, lipids, vitamins, soluble fiber, and minerals, with multiple medical applications in cancer, ${ }^{17}$ inflammation, ${ }^{18}$ allergy, ${ }^{19}$ diabetes,${ }^{20}$ thrombosis, ${ }^{21}$ and obesity (by bringing down the caloric value of the diet), ${ }^{22}$ and may be useful in the reduction of lipid absorption and risk of cardiovascular disease, ${ }^{23}$ hypertension, ${ }^{24}$ and other degenerative diseases. ${ }^{25}$ These biomedical applications of seaweed are mainly due to its functional groups, which act as capping agents in a green single-step process. Polysaccharides are the main constituent of biopolymers in seaweed water extract, and have been found to be strong stabilizers enabling increased biocompatibility. Further, they confer chemical functionality to nanostructures such as $\mathrm{Fe}_{3} \mathrm{O}_{4}$ MNPs. ${ }^{26}$

In a previous study, ${ }^{27}$ we synthesized and characterized $\mathrm{Fe}_{3} \mathrm{O}_{4}$ MNPs using a brown seaweed (Sargassum muticum) extract via the green method. The aim of this study was to investigate the cytotoxic effects of $\mathrm{Fe}_{3} \mathrm{O}_{4}$ MNPs prepared by green biosynthesis on various human cancer cell lines using a number of experimental methods.

\section{Materials and methods Materials}

Specimens of the brown seaweed, Sargassum muticum, were obtained from coastal waters in the Persian Gulf. All aqueous solutions were made using distilled deionized water.

\section{Cell cultures}

All cancer cell lines were purchased from the American Type Culture Collection (ATCC, Rockville, MD, USA), maintained in Roswell Park Memorial Institute 1,640 medium (ATCC) supplemented with L-glutamine $2 \mathrm{mM}$ and $10 \%$ fetal bovine serum (ATCC), with $100 \mathrm{U} / \mathrm{mL}$ penicillin and $100 \mu \mathrm{g} / \mathrm{mL}$ streptomycin (Sigma-Aldrich, St Louis, MO, USA) according to the ATCC protocol, and cultured and grown in $75 \mathrm{~cm}^{2}$ culture flasks (TPP Techno Plastic Products, Trasadingen, Switzerland) at $37^{\circ} \mathrm{C}$ in an incubator with a humidified atmosphere of $95 \%$ air and $5 \% \mathrm{CO}_{2}$ (Binder 
GmbH, Tuttlingen, Germany). The cultures were frequently examined under an inverted microscope (MICROS, Sankt Veit an der Glan, Austria) for confluency and viability.

\section{Methods}

\section{Preparation of S. muticum extract}

As mentioned in our previous study, ${ }^{27}$ the seaweed specimens were washed and stored at $-20^{\circ} \mathrm{C}$. To make the extract, seaweed samples (about $1 \mathrm{~g}$ ) were ground, freeze-dried, and boiled with distilled deionized water $(100 \mathrm{~mL})$ in an Erlenmeyer flask, with constant stirring for 15 minutes. The extract was then cooled to room temperature, filtered, and stored at $-20^{\circ} \mathrm{C}$ before use.

\section{Preparation and characterization of $\mathrm{Fe}_{3} \mathrm{O}_{4}$ MNPs}

$\mathrm{Fe}_{3} \mathrm{O}_{4}$ MNPs (Figure 1) have been prepared and well characterized previously by our group. ${ }^{27}$

\section{Cytotoxicity assay}

The antiproliferative effect of $\mathrm{Fe}_{3} \mathrm{O}_{4}$ MNPs on various cancer cell lines and a normal Chang liver cell line was quantified using a 3-(4,5-dimethylthiazol-2-yl)-2,5 diphenyl tetrazolium bromide (MTT) kit (Sigma-Aldrich) according to the standard method. ${ }^{28}$ Briefly, cells were allowed to grow in a $75 \mathrm{~cm}^{2}$ cell culture flask (TPP Techno Plastic Products, Trasadingen, Switzerland) until 95\% confluent. The cells were then seeded into each well of a 96-well microculture plate (TPP Techno Plastic Products) at a concentration of $1 \times 10^{5}$ cells $/ \mathrm{mL}$ and treated with $\mathrm{Fe}_{3} \mathrm{O}_{4}$ MNPs at various concentrations. After incubation for 72 hours at $37^{\circ} \mathrm{C}$ in a $5 \%$ $\mathrm{CO}_{2}$ incubator (Binder $\mathrm{GmbH}$ ), $25 \mu \mathrm{L}$ of a $5.5 \mathrm{mg} / \mathrm{mL}$ MTT solution was added to each well, covered with aluminum foil, and incubated for a further 3 hours in the dark. Immediately afterwards, the medium was aspirated and the remaining purple formazan was lysed with MTT solution. The assay was performed in triplicate. The optical density was then measured at $570 \mathrm{~nm}$ using an enzyme-linked immunosorbent assay universal microplate reader (Bio Tek Instruments, Inc., VT, USA). The inhibitory concentration $50\left(\mathrm{IC}_{50}\right)$ value was determined from the absorbance versus concentration curve. Dimethyl sulfoxide $0.1 \%$ was used as the negative control.

\section{Acridine orange/propidium iodide assay}

$\mathrm{Fe}_{3} \mathrm{O}_{4} \mathrm{MNP}$-induced death of Jurkat cells was investigated using the acridine orange/propidium iodide double-staining method according to the standard procedure ${ }^{29}$ followed by examination under a fluorescence microscope (Leica, Tokyo, Japan) with Leica Q Fluoro software (Leica) installed. The Jurkat cells were plated at a concentration of $1 \times 10^{6}$ cells $/ \mathrm{mL}$ in a $25 \mathrm{~cm}^{2}$ culture flask (TPP Techno Plastic Products), exposed to $\mathrm{Fe}_{3} \mathrm{O}_{4} \mathrm{MNPs}$ at the $\mathrm{IC}_{50}$, and incubated at $37^{\circ} \mathrm{C}$ in a $5 \% \mathrm{CO}_{2}$ incubator for 24,48 , and 72 hours. Next, the cells were centrifuged at $200 \times g$ (Universal 320R Centrifuge, Andreas Hettich GmbH \& Co.KG, Tuttlingen, Germany) for 10 minutes and the supernatant was discarded. The cells were then washed twice with phosphate-buffered saline after centrifuging at $200 \times g$ for 10 minutes to remove the remaining medium. About $10 \mu \mathrm{L}$ of the cell pellets were stained with a $10 \mu \mathrm{L}$ fluorescent dye mixture containing equal volumes $(100 \mu \mathrm{g} / \mathrm{mL})$ of acridine orange and propidium iodide for 2 minutes. Approximately $10 \mu \mathrm{L}$ of freshly stained cell suspension was placed onto a glass slide, covered with a cover slip, and examined under a fluorescent microscope.

\section{Annexin $\mathrm{V}$-fluorescein isothiocyanate assay}

Jurkat cells $\left(1 \times 10^{6}\right.$ cells $\left./ \mathrm{mL}\right)$ were exposed to the nanoparticles for 12, 24, and 48 hours, with untreated cells used as controls. The cells were then collected and centrifuged at $200 \times g$ (Universal 320R Centrifuge), (Andreas Hettich

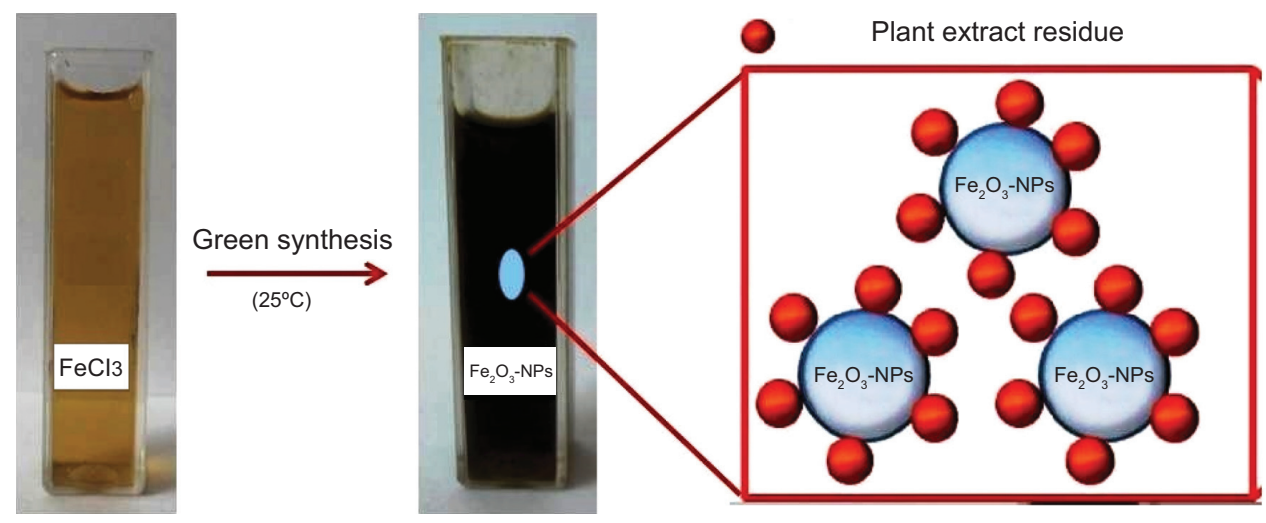

Figure I Magnetic iron oxide nanoparticles synthesized via brown seaweed extract. Abbreviation: NPs; nanoparticles. 
GmbH \& Co.KG) for 10 minutes to remove the medium. The cell pellets were washed twice with $1 \mathrm{~mL}$ of ice-cold phosphate-buffered saline, recentrifuged, and resuspended in ice-cold $1 \times$ binding buffer. Exactly $500 \mu \mathrm{L}$ of cell suspension was transferred to a $5 \mathrm{~mL}$ culture tube (TPP Techno Plastic Products), to which $5 \mu \mathrm{L}$ of Annexin V-fluorescein isothiocyanate (FITC) conjugate and $10 \mu \mathrm{L}$ of propidium iodide were added. The cells were incubated for 15 minutes at room temperature in the dark. Finally, flow cytometry was done under laser emitting excitation light at $488 \mathrm{~nm}$ using a BD FACSCalibur ${ }^{\mathrm{TM}}$ flow cytometer equipped with an argon laser (BD Biosciences, Franklin Lakes, NJ, USA). The data were analyzed using BD CellQuest ${ }^{\mathrm{TM}}$ Pro software (BD Biosciences).

\section{Cell cycle assay}

Flow cytometry was used to investigate the cytotoxicity of $\mathrm{Fe}_{3} \mathrm{O}_{4}$ MNPs in Jurkat cells. Briefly, Jurkat cells $\left(2.0 \times 10^{6}\right.$ cells $\left./ \mathrm{mL}\right)$ were cultured with the $\mathrm{IC}_{50}$ of $\mathrm{Fe}_{3} \mathrm{O}_{4} \mathrm{MNPs}$ and incubated for 24, 48, and 72 hours. The cells were harvested by centrifugation at $1,500 \mathrm{rpm}$ for 5 minutes and washed with phosphate-buffered saline. Next, $600 \mu \mathrm{L}$ of $70 \%$ ice-cold ethanol were added to the cell pellets, which were then kept at $-20^{\circ} \mathrm{C}$ overnight. A $1 \mathrm{~mL}$ volume of phosphate-buffered saline was added and spun down at 1,500 rpm for 5 minutes to remove the ethanol. The cell pellets were then washed twice with phosphate-buffered saline, stained with staining buffer containing $0.1 \%$ Triton X-100 (Sigma-Aldrich), $10 \mathrm{mM}$ ethylenediaminetetraacetic acid (Sigma-Aldrich), $50 \mu \mathrm{g} / \mathrm{mL}$ Ribonuclease A (Sigma-Aldrich), and $3 \mu \mathrm{g} / \mathrm{mL}$ propidium iodide (SigmaAldrich), and incubated in the dark on ice for 30 minutes. Flow cytometry was performed with laser emitting excitation light at $488 \mathrm{~nm}$ using a FACSCalibur ${ }^{\mathrm{TM}}$ flow cytometer equipped with an argon laser (BD Biosciences). The data analysis was performed using CellQuest ${ }^{\mathrm{TM}}$ Pro software.

\section{Caspase- 3 and caspase- 9 assays}

The activity of caspase- 3 and caspase- 9 in Jurkat cells treated with $\mathrm{Fe}_{3} \mathrm{O}_{4}$ MNPs was determined after 24, 48, and 72 hours using a colorimetric assay kit (BD Biosciences) according to the manufacturer's instructions without modification.

\section{Statistical analysis}

The experiments were done in triplicate, and the results are expressed as the mean \pm standard deviation. The statistical analysis was done using IBM $^{\circledR}$ SPSS $^{\circledR}$ Statistics for Windows version 20.0 software (IBM Corp., Armonk, NY, USA). $P$-values $<0.05$ were considered to be statistically significant.

\section{Results and discussion $\mathrm{Fe}_{3} \mathrm{O}_{4}$ MNPs inhibit proliferation of human cancer cells}

Observation of morphological changes in cells indicated that $\mathrm{Fe}_{3} \mathrm{O}_{4}$ MNPs inhibited proliferation of the various cancer cell lines in a dose-dependent and time-dependent manner (Figure 2A). No toxicity was seen in the normal Chang liver cell line (Figure 2B). The $\mathrm{IC}_{50}$ values calculated for $\mathrm{Fe}_{3} \mathrm{O}_{4}$ MNPs in the various cancer cell lines were $23.83 \pm 1.1 \mu \mathrm{g} / \mathrm{mL}$ (HepG2), 18.75 $\pm 2.1 \mu \mathrm{g} / \mathrm{mL}$ (MCF-7), $12.5 \pm 1.7 \mu \mathrm{g} / \mathrm{mL}$ (HeLa), and $6.4 \pm 2.3 \mu \mathrm{g} / \mathrm{mL}$ (Jurkat) after treatment for 72 hours. Therefore, Jurkat cells were selected for further investigation.

It is relevant to the evaluation toxicity of metal nanoparticles against cancer cells as many studies have already published. Coradeghini et al reported that BALB/C-3T3 mouse fibroblasts at higher doses than $50 \mu \mathrm{M}$ for 72 hours of exposure to gold nanoparticles with a thickness of $5 \mathrm{~nm}$, as compared with $15 \mathrm{~nm}$, induced dose-dependent cell cytotoxicity. They reported that the size of gold nanoparticles is an important indicator of potential application in the biomedical field..$^{30}$ Another recent study reported that different types of iron oxide nanoparticles demonstrate diverse biological activity as a result of versatile surface coating. Novotna et al
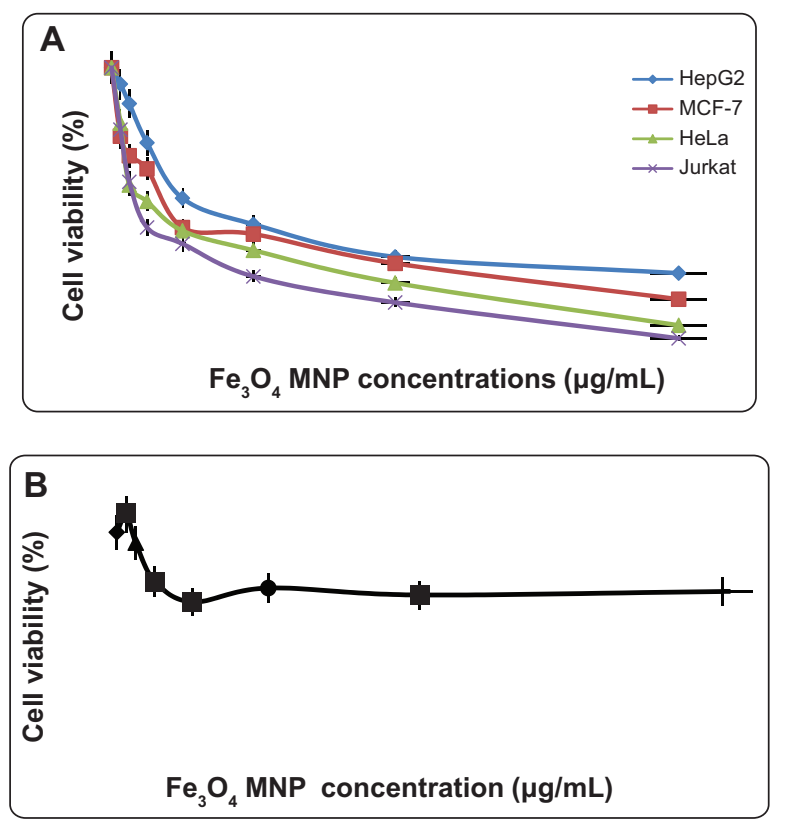

Figure 2 (A) The cytotoxic effect of $\mathrm{Fe}_{3} \mathrm{O}_{4}$ MNPs on various cancer cell lines after 72 hours of treatment evaluated by mitochondrial activity using the MTT assay. Each point represents the mean value of three replicates. (B) The cytotoxic effect of $\mathrm{Fe}_{3} \mathrm{O}_{4}$ MNPs on a normal Chang human liver cell line after 72 hours of treatment evaluated with MTT assay. Each point represents the mean value of three replicates.

Abbreviations: $\mathrm{Fe}_{3} \mathrm{O}_{4}$ MNPs, magnetic iron oxide nanoparticles; MTT, 3-(4,5dimethylthiazol-2-yl)-2,5 diphenyl tetrazolium bromide. 

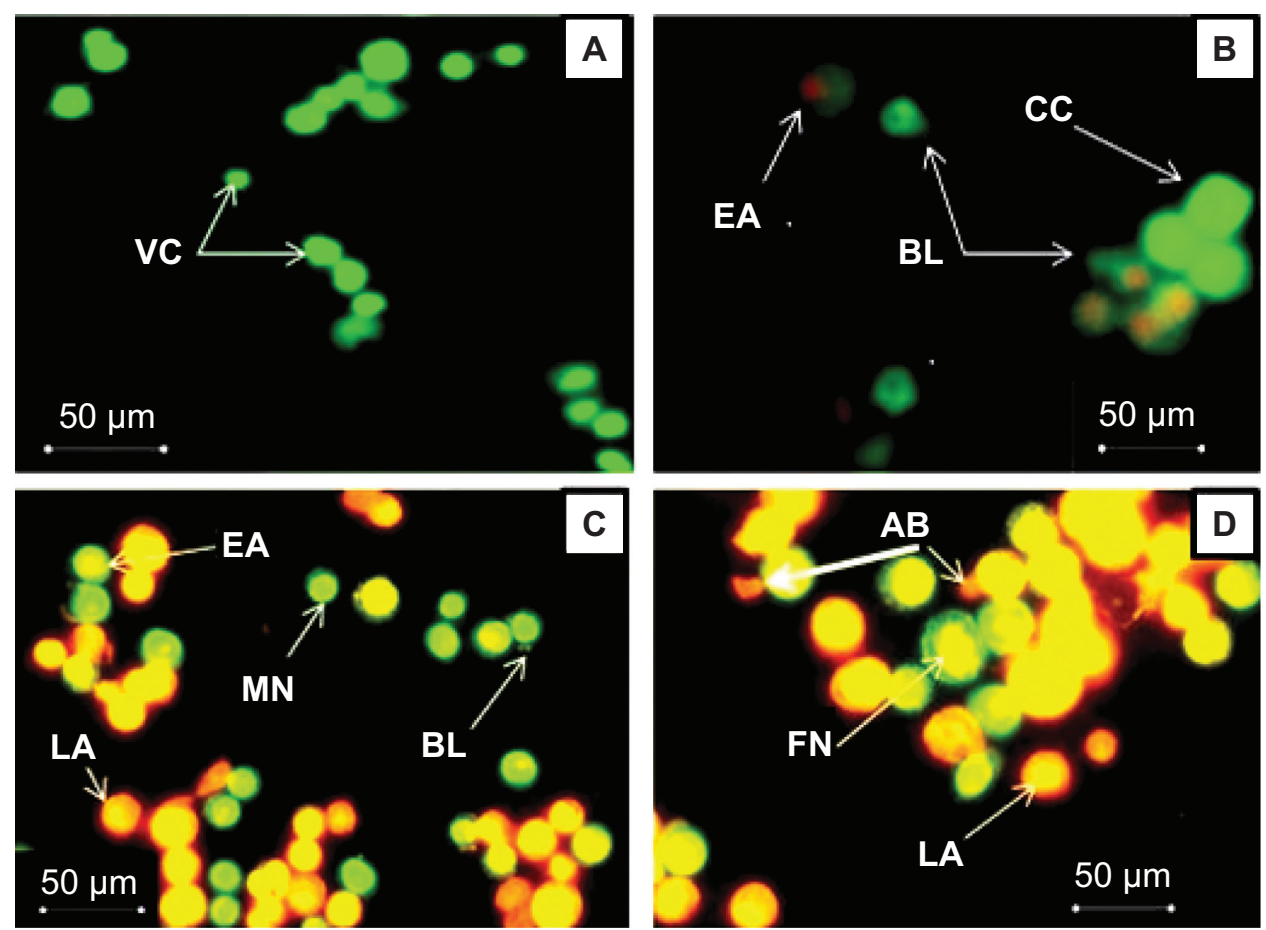

Figure 3 Fluorescent micrographs of acridine orange/propidium iodide double-stained Jurkat cells treated with Fe $\mathrm{O}_{4} \mathrm{MNPs}$. (A) Untreated cells showing normal cell structure, (B) early apoptotic cells after 24 hours of treatment showing membrane blebbing and chromatin condensation, (C) blebbing and nuclear margination after 48 hours of treatment, and (D) DNA fragmentation and apoptotic body formation after 72 hours of treatment.

Abbreviations: VC, viable cells; EA, early apoptotic cells; CC, chromatin condensation; BL, membrane blebbing; MN, marginated nucleus; FN, fragmented nucleus; LA, late apoptotic cells; $\mathrm{AB}$, apoptotic body; $\mathrm{Fe}_{3} \mathrm{O}_{4} \mathrm{MNPs}$, magnetic iron oxide nanoparticles; DNA, deoxyribonucleic acid.

examined the effect of superparamagnetic iron oxide nanoparticles on human bone marrow mesenchymal stromal cells from two donors. Their results showed only hBMSCs-2 were sensitive to these nanoparticles; however, increased oxidative injury to lipids, proteins, and DNA was detected in cells from both donors. ${ }^{31}$

Schweigera et al reported on $\mathrm{Fe}_{3} \mathrm{O}_{4}$ MNPs stabilized with poly(ethyleneimine)-g-poly(ethylene glycol) and branched poly(ethyleneimine). They also evaluated the cytotoxic effects of polymer-coated iron oxide nanoparticles in A549 epithelial adenocarcinoma cells. Their findings for cell viability showed that poly(ethyleneimine) layered onto iron oxide nanoparticles produced significant cytoxicity compared to free poly(ethyleneimine) polymer. ${ }^{11}$

\section{Quantification of apoptosis using acridine orange/propidium iodide double-staining}

Induction of apoptosis is a useful strategy in the treatment of cancer. Several cellular and molecularbiological features can be demonstrated in apoptotic cells, including cell shrinkage, DNA fragmentation, and activation of the caspase cascade. The cytotoxicity of $\mathrm{Fe}_{3} \mathrm{O}_{4}$ MNPs was evaluated by inhibition of cell growth. When the growth-inhibited cells were stained with acridine orange/propidium iodide, apoptotic cell death was observed in a time-dependent and dose-dependent manner in all cultures (Figure 3).

Intact membranes exclude propidium iodide, but allow uptake of acridine orange, which binds to double-stranded DNA and fluoresces green under $488 \mathrm{~nm}$ excitation. Untreated cells show diffuse green fluorescence, while apoptotic cells (containing condensed chromatin material) show clumps of intense green fluorescent spots within the cell. Characteristic condensation patterns were observed such as crescent shapes found at the nuclear periphery and an increase in the number of round clumps.

\section{Annexin V-FITC assay}

The apoptotic effect induced by the $\mathrm{Fe}_{3} \mathrm{O}_{4}$ MNPs was investigated further by determining the percentage of apoptotic cells using flow cytometric analysis with Annexin V/propidium iodide double-staining. Annexin V-positive/propidium iodide-negative staining indicated cells in early apoptosis due to the strong affinity of Annexin V-FITC for phosphatidylserine, which transports Annexin $\mathrm{V}$ protein from the inner leaflet of the plasma membrane to the outer surface of the membrane during early apoptosis. On the other hand, Annexin V-negative/propidium iodide-positive staining indicates necrotic cells, since propidium iodide, which cannot pass 
through an intact cell membrane, penetrates the compromised membranes of cells that are dead or in late apoptosis, and binds to nucleic acids. Meanwhile, Annexin V-negative/ propidium iodide-negative staining indicates viable cells and Annexin V-positive/propidium iodide-positive staining indicates cells in late apoptosis. The representative dot plots for the flow cytometric analysis comparing untreated cells and treated cells (at 12, 24, and 48 hours) showed an increase in the percentages of treated cells in early apoptosis and late apoptosis (Figure 4 and Table 1). In addition, exposure to $\mathrm{Fe}_{3} \mathrm{O}_{4}$ MNPs resulted in a slight decrease in the amount of viable cells at 12, 24, and 48 hours. These results suggest that the antiproliferative effect of $\mathrm{Fe}_{3} \mathrm{O}_{4}$ MNPs on Jurkat cells results from induction of cell apoptosis.

\section{Cell cycle assay}

In cells treated with agents that induce apoptosis, a subpopulation of cells appears before the G1 peak and is
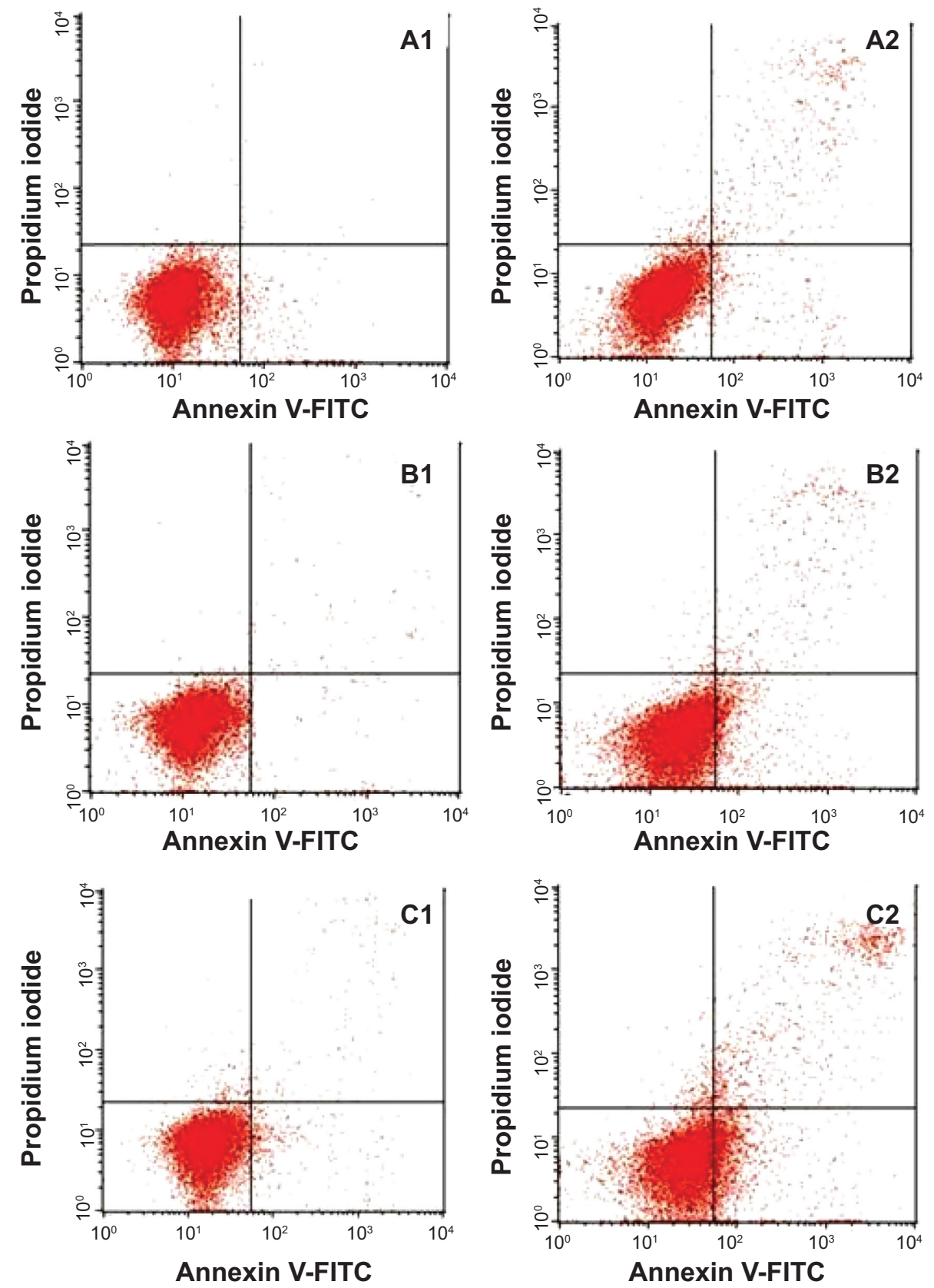

Figure 4 Flow cytometric analysis of induction of apoptosis in Jurkat cells by $\mathrm{Fe}_{3} \mathrm{O}_{4}$ MNPs after staining with FITC-conjugated Annexin $\mathrm{V}$ and propidium iodide. (AI-CI) Untreated (control) Jurkat cells after I2, 24, and 48 hours of incubation, respectively. (A2-C2) Effects of I2, 24, and 48 hours of treatment with Fe $\mathrm{O}_{4}$ MNPs, respectively. Abbreviations: $\mathrm{Fe}_{3} \mathrm{O}_{4}$ MNPs, magnetic iron oxide nanoparticles; Annexin V-FITC, annexin V-conjugated fluorescein isothiocyanate. 
Table I Flow cytometric analysis of Jurkat cells treated with $\mathrm{Fe}_{3} \mathrm{O}_{4} \mathrm{MNPs}$

\begin{tabular}{lllllll}
\hline Cells (\%) & & & & & \\
\hline Cell & Control & Treated & Control & Treated & Control & Treated \\
Condition & $\mathbf{I}$ hours & $\mathbf{I}$ hours & $\mathbf{2 4}$ hours & $\mathbf{2 4}$ hours & $\mathbf{4 8}$ hours & $\mathbf{4 8}$ hours \\
\hline Viable cells & $95.54 \pm 0.11$ & $89.59 \pm 0.26$ & $93.33 \pm 0.55$ & $85.29 \pm 0.16$ & $93.78 \pm 0.26$ & $74.98 \pm 0.33$ \\
Early apoptosis & $1.77 \pm 0.14$ & $4.75 \pm 0.6 I^{*}$ & $1.98 \pm 0.57$ & $8.00 \pm 0.38^{*}$ & $3.15 \pm 0.4 \mathrm{I}$ & $15.04 \pm 0.52^{*}$ \\
Late apoptosis/necrosis & $2.69 \pm 0.34$ & $5.66 \pm 0.95^{* *}$ & $4.69 \pm 0.50$ & $7.7 I \pm 0.82^{* *}$ & $3.07 \pm 0.25$ & $9.98 \pm 0.50^{* *}$ \\
\hline
\end{tabular}

Notes: The cells were stained with FITC-conjugated Annexin $V$ and propidium iodide, then incubated at $37^{\circ} \mathrm{C}$ for 12,24 , and 48 hours. $V$ alues are expressed as the mean \pm standard deviation of three different experiments. The data were analyzed using post hoc comparison test-one way analysis of variance, and means were compared by Tukey's $B$ test. *Significant $(P<0.05)$ increase in early apoptotic cells in $\mathrm{Fe}_{3} \mathrm{O}_{4}$ MNP-treated groups compared with untreated controls. **Significant $(P<0.05)$ increase in late apoptotic/ necrotic cells in $\mathrm{Fe}_{3} \mathrm{O}_{4}$ MNP-treated groups compared with untreated controls.

Abbreviations: $\mathrm{Fe}_{3} \mathrm{O}_{4}$ MNP, magnetic iron oxide nanoparticles; FITC, fluorescein isothiocyanate.

referred to as the sub-G1 peak. This is believed to be the result of endonuclease activation and subsequent leakage of DNA from the cells. Necrotic cells do not show an immediate reduction in DNA content, so a clear distinction could be made between necrotic and apoptotic cells. As shown in Figure 5 and Table 2, the sub-G1 population, indicating apoptotic cells, increased in a time-dependent manner from $10.10 \pm 0.2824$ hours after exposure to $\mathrm{Fe}_{3} \mathrm{O}_{4}$ MNPs to $20.0 \pm 0.20$ after 48 hours and $23.85 \pm 0.56$ after 72 hours. Regulation of the cancer cell cycle is a potential strategy in the development of anticancer drugs. Xia et al showed a shift of cell distribution into the G2/M
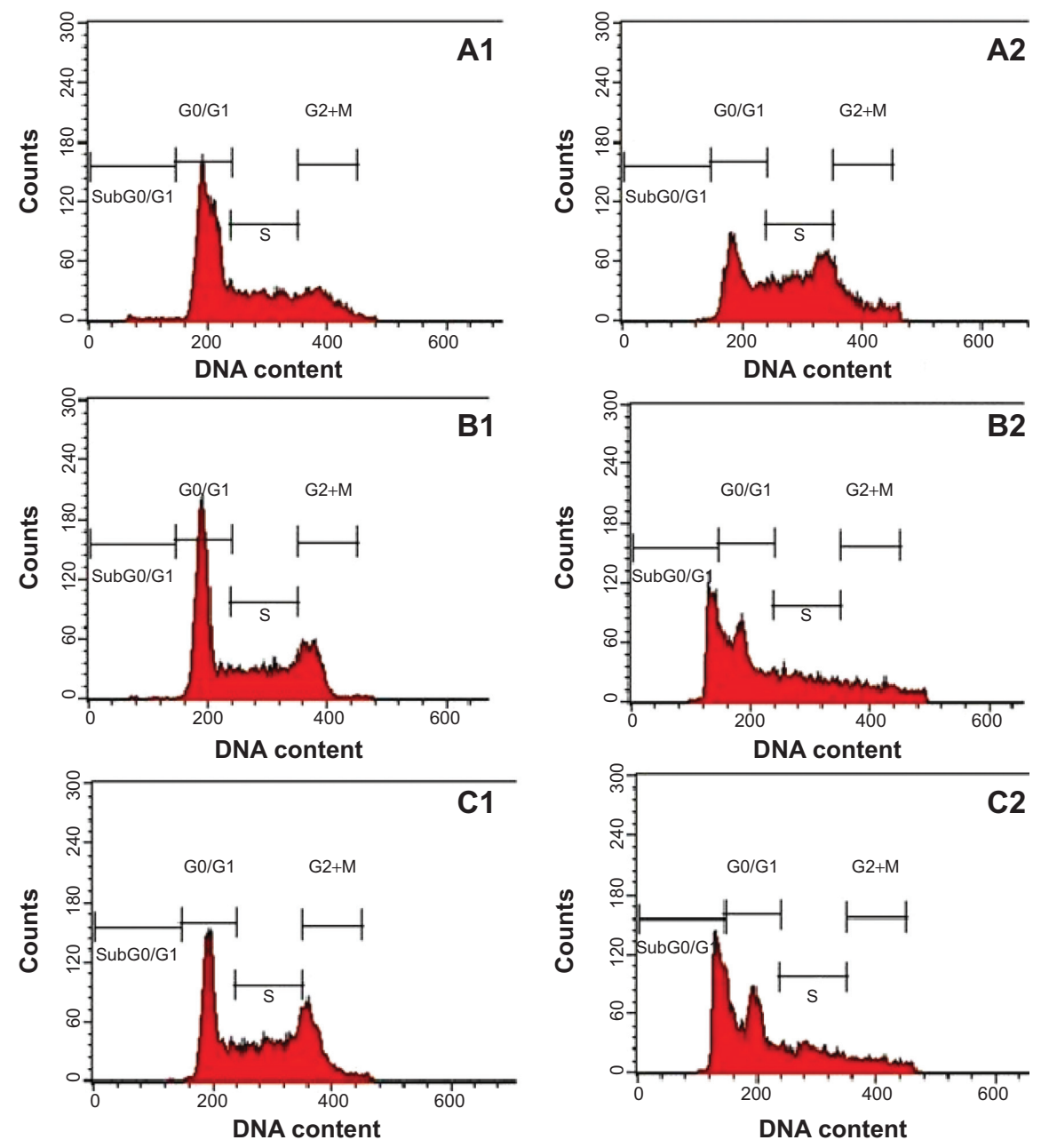

Figure 5 Cell cycle analysis of Jurkat cells treated with $\mathrm{Fe}_{3} \mathrm{O}_{4}$ MNPs after staining with propidium iodide. (AI-CI) Untreated Jurkat cells treated for 24,48 , and 72 hours, respectively. (A2-C2) Effects of 24,48 , and 72 hours of exposure of Jurkat cells to $\mathrm{Fe}_{3} \mathrm{O}_{4}$ MNPs, respectively. G0/GI, G2/M, and S indicate the cell phase, and sub-G0/GI refers to the proportion of apoptotic cells.

Abbreviations: $\mathrm{Fe}_{3} \mathrm{O}_{4} \mathrm{MNPs}$, magnetic iron oxide nanoparticles; DNA, deoxyribonucleic acid. 
Table 2 Flow cytometric analysis of Jurkat cells treated with $\mathrm{Fe}_{3} \mathrm{O}_{4} \mathrm{MNPs}$

\begin{tabular}{lllllll}
\hline Cells (\%) & & & & & \\
\hline Cell cycle & Control & Treated & Control & Treated & Control & Treated \\
phases & $\mathbf{2 4}$ hours & $\mathbf{2 4}$ hours & $\mathbf{4 8}$ hours & $\mathbf{4 8}$ hours & $\mathbf{7 2}$ hours & $\mathbf{7 2}$ hours \\
\hline G0/GI & $56.25 \pm 0.06$ & $33.44 \pm 0.45$ & $51.13 \pm 0.29$ & $42.61 \pm 0.52$ & $37.64 \pm 0.32$ & $45.68 \pm 0.68$ \\
G2/M & $17.85 \pm 0.76$ & $18.29 \pm 0.4 I$ & $20.16 \pm 0.26$ & $12.29 \pm 0.35$ & $24.22 \pm 0.22$ & $10.06 \pm 0.93$ \\
Synthesis & $24.91 \pm 0.06$ & $38.23 \pm 0.33$ & $29.24 \pm 0.06$ & $22.93 \pm 0.12$ & $38.95 \pm 0.61$ & $21.35 \pm 0.18$ \\
Sub G0/GI & $0.98 \pm 0.23$ & $10.10 \pm 0.28 *$ & $0.20 \pm 0.34$ & $20.0 \pm 0.20^{*}$ & $0.02 \pm 0.46$ & $23.85 \pm 0.56 *$ \\
\hline
\end{tabular}

Notes: The cells were stained with propidium iodide and incubated at $37^{\circ} \mathrm{C}$ for 24,48 , and 72 hours. Values are expressed as the mean \pm standard deviation of three different experiments. The data were analyzed using post hoc comparison test-one way analysis of variance, and means were compared by Tukey's $B$ test. *Significant $(P<0.05)$ increase of cells in sub-G0/GI phase in $\mathrm{Fe}_{3} \mathrm{O}_{4}$ MNP-treated groups compared with untreated controls.

Abbreviation: $\mathrm{Fe}_{3} \mathrm{O}_{4} \mathrm{MNP}$, magnetic iron oxide nanoparticles.

phase, which was enhanced by $\mathrm{Fe}_{3} \mathrm{O}_{4}$ MNPs. ${ }^{32}$ Our data indicate that the sub-G1 population, ie, apoptotic cells, increased in a time-dependent manner, whereas other researchers have reported cells arrested in G1/S and in both G1/S and G2/M. ${ }^{32}$ These conflicting results suggest that there may be fundamental differences between cell types.

\section{Caspase assay}

The apoptotic effect of $\mathrm{Fe}_{3} \mathrm{O}_{4}$ MNPs was also examined by determining caspase- 3 and caspase- 9 activity relative to varying concentrations of protein content for cells treated with the $\mathrm{IC}_{50}$ of $\mathrm{Fe}_{3} \mathrm{O}_{4}$ MNPs. Our results show that enzyme activity increased in a time-dependent manner, as shown in Figure 6 and Table 3.

Apoptosis is orchestrated by a family of cysteine proteases known as caspases. The main effectors of apoptosis encompass proteases from the caspase family, which reside as latent precursors in most nucleated animal cells. Fourteen mammalian caspases have been identified, three of which (caspase-3, caspase-6, and caspase-7) are

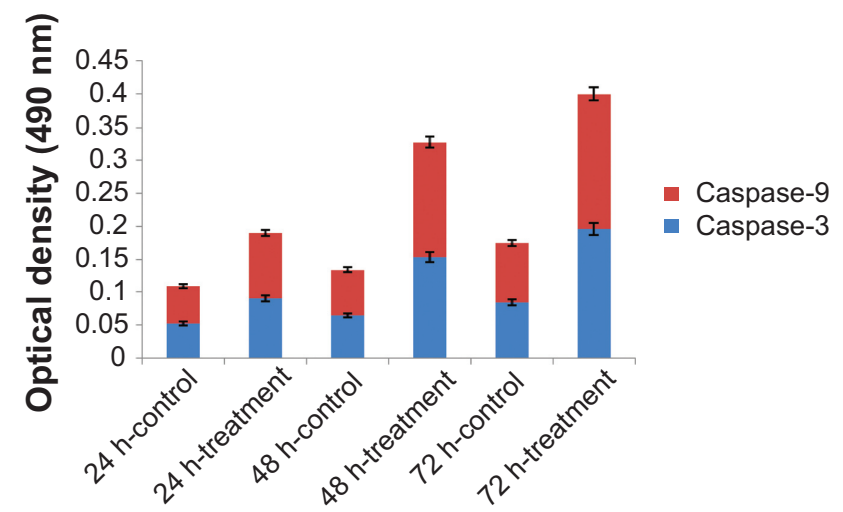

Figure 6 Effect of treatment with $\mathrm{Fe}_{3} \mathrm{O}_{4}$ MNPs on caspase- 3 and caspase- 9 activity in Jurkat cells. The values represent the mean \pm standard deviation of three independent experiments. Significant differences $(P<0.05)$ in caspase- 3 and caspase- 9 activity were found between the treated and control groups.

Abbreviation: $\mathrm{Fe}_{3} \mathrm{O}_{4}$ MNPs, magnetic iron oxide nanoparticles. thought to coordinate the execution phase of apoptosis by cleaving multiple structural and repair proteins. Pathways to caspase-3 activation have been identified, which are either dependent on or independent of release of mitochondrial cytochrome $\mathrm{c}$ and caspase-9 function. Caspase-3 activation is the hallmark of apoptosis, and is necessary for apoptotic chromatin condensation and DNA fragmentation in all cell types examined. Thus, caspase- 3 is essential for certain processes associated with dismantling of the cell and the formation of apoptotic bodies. However, it may also function before or at the stage when commitment to loss of cell viability is made. As shown in Figure 6, $\mathrm{Fe}_{3} \mathrm{O}_{4}$ MNPs increased the activity of caspase- 9 and caspase- 3 in a timedependent manner. According to studies of caspase activity, several distinct pathways exist, resulting in induction of apoptosis by $\mathrm{Fe}_{3} \mathrm{O}_{4}$ MNPs. In our study, we noted that $\mathrm{Fe}_{3} \mathrm{O}_{4}$ MNPs activated caspase- 3 and caspase- 9 in a timeresponse manner.

\section{Conclusion}

$\mathrm{Fe}_{3} \mathrm{O}_{4}$ MNPs with different sizes and characteristics have been developed and widely investigated in a number of biomedical applications. Stabilizing and preventing formation of aggregation are critical for controlling chemical reactions, which provide dependable, well-dispersed size and consistency. In this study, we investigated the toxicity of $\mathrm{Fe}_{3} \mathrm{O}_{4} \mathrm{MNPs}$ in human leukemia (Jurkat) cells. Our results show that exposure of Jurkat cells to $\mathrm{Fe}_{3} \mathrm{O}_{4}$ MNPs results in significant cytotoxicity, with an apoptotic response, but not in a normal Chang liver cell line, providing new opportunities for safe delivery of $\mathrm{Fe}_{3} \mathrm{O}_{4}$ MNPs and application in anticancer therapy.

\section{Acknowledgment}

The authors are grateful to the staff of Universiti Putra Malaysia for their help with this research, and to the Department of 
Table 3 Spectrophotometric analysis of caspases in Jurkat cells treated with $\mathrm{Fe}_{3} \mathrm{O}_{4} \mathrm{MNPs}$ for 24,48 , and 72 hours

\begin{tabular}{lllllll}
\hline Cells \% & & & & & \\
\hline Caspase & Control & Treated & Control & Treated & Control & Treated \\
& $\mathbf{2 4}$ hours & $\mathbf{2 4}$ hours & $\mathbf{4 8}$ hours & $\mathbf{4 8}$ hours & $\mathbf{7 2}$ hours & $\mathbf{7 2}$ hours \\
\hline Caspase-3 & $0.057 \pm 0.003$ & $0.095 \pm 0.00 I^{*}$ & $0.068 \pm 0.010$ & $0.158 \pm 0.025^{*}$ & $0.080 \pm 0.095$ & $0.199 \pm 0.055^{*}$ \\
Caspase-9 & $0.059 \pm 0.001$ & $0.102 \pm 0.009^{*}$ & $0.07 \pm 0.081$ & $0.179 \pm 0.016^{*}$ & $0.095 \pm 0.039$ & $0.207 \pm 0.031^{*}$ \\
\hline
\end{tabular}

Notes: Values are expressed as the mean \pm standard deviation of three different experiments. The data were analyzed using post hoc comparison test-one way analysis of variance, and means were compared by Tukey's B test. *Significant $(P<0.05)$ increase in apoptotic cells in $\mathrm{Fe}_{3} \mathrm{O}_{4} \mathrm{MNP}$-treated groups compared with untreated controls. Abbreviation: $\mathrm{Fe}_{3} \mathrm{O}_{4} \mathrm{MNP}$, magnetic iron oxide nanoparticles.

Chemistry, Faculty of Science, Universiti Putra Malaysia, for allowing us to use its laboratory facilities and providing technical assistance.

\section{Disclosure}

The authors report no conflicts of interest in this work.

\section{References}

1. Maeng JH, Lee DH, Jung KH, et al. Multifunctional doxorubicin loaded superparamagnetic iron oxide nanoparticles for chemotherapy and magnetic resonance imaging in liver cancer. Biomaterials. 2010;31:4995-5006.

2. Kim PS, Djazayeri S, Zeineldin R. Novel nanotechnology approaches to diagnosis and therapy of ovarian cancer. Gynecol Oncol. 2011;120: 393-403.

3. Wang LS, Chuang MC, Ho JA. Nanotheranostics - a review of recent publications. Int J Nanomedicine. 2012;7:4679-4695.

4. Salam HA, Rajiv P, Kamaraj M, Jagadeeswaran P, Gunalan S, Sivaraj R. Plants: green route for nanoparticle synthesis. Int Res J Biol Sci. 2012;1:85-90.

5. Santhosh PB, Ulrih NP. Multifunctional superparamagnetic iron oxide nanoparticles: promising tools in cancer theranostics. Cancer Lett. 2013;336:8-17.

6. Jayapaul J, Hodenius M, Arns S, et al. FMN-coated fluorescent iron oxide nanoparticles for RCP-mediated targeting and labeling of metabolically active cancer and endothelial cells. Biomaterials. 2011;32: 5863-5871.

7. Hyuk W, Suslick KS, Stucky GD, Suh Y. Nanotechnology, nanotoxicology, and neuroscience. Prog Neurobiol. 2009;87:133-170.

8. Indhira TK, Lakshmi PK. Magnetic nanoparticles - a review. Int J Pharmacol Sci Nanotechnol. 2010;2:1035-1042.

9. Guoa J, Wang R, Tjiu W, Pan J, Liu T. Synthesis of Fe nanoparticles@ graphene composites for environmental applications. J Hazard Mater. 2012;225-226:63-73.

10. Wang X, Wei F, Liu A, et al. Cancer stem cell labeling using poly (L-lysine)-modified iron oxide nanoparticles. Biomaterials. 2012;33 3719-3732.

11. Schweiger C, Pietzonka C, Heverhagen J, Kissel T. Novel magnetic iron oxide nanoparticles coated with poly(ethyleneimine)g-poly(ethylene glycol) for potential biomedical application: synthesis, stability, cytotoxicity and MR imaging. Int J Pharm. 2011;408 130-137.

12. Ling Y, Wei K, Luo Y, Gao X, Zhong S. Dual docetaxel/ superparamagnetic iron oxide loaded nanoparticles for both targeting magnetic resonance imaging and cancer therapy. Biomaterials. 2011;32: 7139-7150.

13. Khan MI, Mohammad A, Patil G, Naqvi SA, Chauhan LK, Ahmad I. Induction of ROS, mitochondrial damage and autophagy in lung epithelial cancer cells by iron oxide nanoparticles. Biomaterials. 2012;33:1477-1488.
14. Rajapakse N, Kim S-K. Nutritional and Digestive Health Benefits of Seaweed. 1st ed. Philadelphia, PA, USA: Elsevier Inc; 2011.

15. Namvar F, Baharara J, Mahdi A. Antioxidant and anticancer activities of selected Persian Gulf algae. Ind J Clin Biochem. 2014;29: $13-20$.

16. Namvar F, Paridah MT, Mohamad R, et al. Biomedical properties of edible seaweed in cancer therapy and chemoprevention trials: a review. Nat Prod Commun. 2013;8:1811-1820.

17. Namvar F, Suhaila M, Gasemi Fard S, Behravan J. Polyphenol-rich seaweed (Eucheuma cottonii) extract suppresses breast tumour via hormone modulation and apoptosis induction. Food Chem. 2012;130: 376-382.

18. Khan M, Choi J, Lee M, Kim E, Nam T. Anti-inflammatory activities of methanol extracts from various seaweed species. Environ Biol. 2008;29: 465-469.

19. Zuercher AW, Fritsché R, Corthésy B, Mercenier A. Food products and allergy development, prevention and treatment. Curr Opin Biotechnol. 2006; 17:198-203.

20. Perez GR, Zavala SM, Perez GS, Perez G. Antidiabetic effect of compounds isolated from plants. Phytomedicine. 1998;5:55-75.

21. Nishino T, Fukuda A, Nagumo T, Fujihara M, Kaji E. Inhibition of the generation of thrombin and factor Xa by a fucoidan from the brown seaweed Ecklonia kurome. Thromb Res. 1999;96:37-49.

22. Miyashita K.The carotenoid fucoxanthin from brown seaweed affects obesity. Lipid Technol. 2009;21:186-190.

23. Mohamed S, Hashim SN, Rahman H. Seaweeds: a sustainable functional food for complementary and alternative therapy. Trends Food Sci Technol. 2012;23:83-96.

24. Wada K, Nakamura K, Tamai Y. Seaweed intake and blood pressure levels in healthy pre-school Japanese children. Nutr J. 2011;10: $83-88$.

25. Namvar F, Mohamad R, Baharara J, Zafar-Balanejad S, Fargahi F, Rahman HS. Antioxidant, antiproliferative, and antiangiogenesis effects of polyphenol-rich seaweed (Sargassum muticum). Biomed Res Int. 2013;2013:1-9.

26. Dias AM, Hussain A, Marcos AS, Roque AA. A biotechnological perspective on the application of iron oxide magnetic colloids modified with polysaccharides. Biotechnol Adv. 2011;29:142-155.

27. Mahdavi M, Namvar F, Ahmad MB, Mohamad R. Green biosynthesis and characterization of magnetic iron oxide $\left(\mathrm{Fe}_{3} \mathrm{O}_{4}\right)$ nanoparticles using seaweed (Sargassum muticum) aqueous extract. Molecules. 2013;18:5954-5964.

28. Van de Loosdrecht A, Beelen R, Ossenkoppele GJ, et al. A tetrazoliumbased colorimetric MTT assay to quantitate human monocyte mediated cytotoxicity against leukemic cells from cell lines and patients with acute myeloid leukemia. J Immunol Methods. 1994;174: 311-320.

29. Fan C, Wang W, Zhao B, Zhang S, Miao J. Chloroquine inhibits cell growth and induces cell death in A549 lung cancer cells. Bioorg Med Chem. 2006;14:3218-3222.

30. Coradeghini R, Gioria S, García CP, et al. Size-dependent toxicity and cell interaction mechanisms of gold nanoparticles on mouse fibroblasts. Toxicol Lett. 2013;217:205-216. 
31. Novotna B, Jendelova P, Kapcalova M, et al. Oxidative damage to biological macromolecules in human bone marrow mesenchymal stromal cells labeled with various types of iron oxide nanoparticles. Toxicol Lett. 2012;210:53-63.
32. Xia G, Chen B, Ding J, et al. Effect of magnetic $\mathrm{Fe}_{3} \mathrm{O}_{4}$ nanoparticles with 2-methoxyestradiol on the cell-cycle progression and apoptosis of myelodysplastic syndrome cells. Int J Nanomedicine. 2011;6:1921-1927.

\section{Publish your work in this journal}

The International Journal of Nanomedicine is an international, peerreviewed journal focusing on the application of nanotechnology in diagnostics, therapeutics, and drug delivery systems throughout the biomedical field. This journal is indexed on PubMed Central, MedLine, CAS, SciSearch $®$, Current Contents ${ }^{\circledR} /$ Clinical Medicine,
Journal Citation Reports/Science Edition, EMBase, Scopus and the Elsevier Bibliographic databases. The manuscript management system is completely online and includes a very quick and fair peer-review system, which is all easy to use. Visit http://www.dovepress.com/ testimonials.php to read real quotes from published authors.

Submit your manuscript here: http://www.dovepress.com/international-journal-of-nanomedicine-journal 